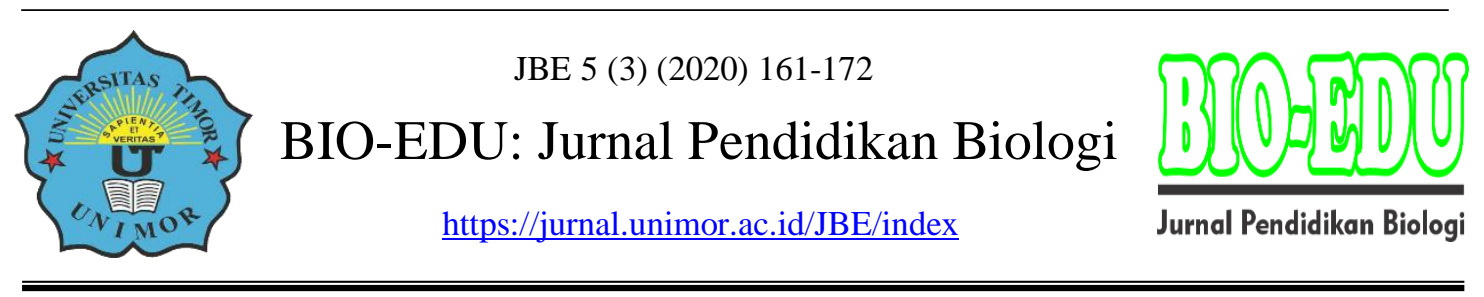

\title{
Intraspecies Relationship of Croton (Codiaeum variegatum L.) in South Parigi District Based on Phenetic Analysis
}

\section{Hubungan Kekerabatan Intraspesies Tanaman Puring (Codiaeum variegatum L.) di Kecamatan Parigi Selatan Berdasarkan Analisis Fenetik}

\author{
Sukmawati ${ }^{1}$, Manap Trianto ${ }^{2}$, Nuraini ${ }^{3}$ \\ ${ }^{1}$ Departemen Biologi Tropika, Fakultas Biologi, Universitas Gadjah Mada \\ E-mail: manaptrianto@mail.ugm.ac.id
}

DOI: https://DOI 10.32938/jbe. v5i3.733

\begin{abstract}
Abstrak
Puring merupakan salah satu komoditas tanaman hortikultura yang penting dikalangan masyarakat karena berperan menambah kecantikan maupun keindahan serta berfungsi sebagai tanaman penyerap polutan. Tujuan penelitian ini yaitu untuk mendeskripsikan hubungan kekerabatan antara kultivar tanaman puring. Penelitian dilaksanakan pada bulan Mei 2020. Jenis penelitian yang digunakan yaitu deskriptif eksploratif. Sampel penelitian yang digunakan adalah 8 kultivar tanaman puring dengan 5 individu pada masing-masing kultivar. Karakter tanaman yang diukur meliputi 14 karakter morfometrik, 6 karakter meristik, dan 81 karakter kualitatif. Analisis hubungan kekerabatan diolah menggunakan software Program File Editor (PFE) dan Multivariat Statistical Package (MVSP). Besarnya indeks similaritas dihitung menggunakan metode Simple Matching Coefficient, dan penentuan hubungan kekerabatan menggunakan UPGMA algorithm. Hasil penelitian menunjukkan bahwa diperole 8 kultivar dan membentuk 3 klaster dan 2 subklaster. Hubungan kekerabatan terdekat yaitu antara puring lele dan puring seribu bintang yang didukung dengan indeks similaritas 0,766 dan hubungan kekerabatan terjauh terjadi antara node 6 (puring bor, emping, kerupuk, lele, seribu bintang dan walet) dan node 3 (puring domba dan kura-kura) yang didukung dengan indeks similaritas yaitu 0,6.
\end{abstract}

Kata Kunci: Hubungan kekerabatan, intraspesies; tanaman puring; Parigi Moutong; Fenetik

\begin{abstract}
Croton is one of the horticultural plant commodities that is important among the community because it plays a role in adding beauty and beauty and functions as a pollutant absorbent plant. This reseach is aims to describe the kinship relationship between croton cultivars. The research was conducted in May 2020. The type of research used is descriptive exploratory. The research sample used was eight croton cultivars with five individuals in each cultivar. The plant characters measured included 14 morphometric characters, six meristic characters, and 81 qualitative characters. Kinship analysis was processed using the File Editor Program (PFE) software and the Multivariate Statistical Package (MVSP). The amount of the similarity index is calculated using the Simple Matching Coefficient method, and the determination of kinship using the UPGMA algorithm. The results showed that eight cultivars were obtained and formed 3 clusters and two sub-clusters. The closest kinship relationship is between croton lele and croton with a thousand stars which are supported by a similarity index of 0.766 and the farthest relationship occurs between node 6
\end{abstract}


(croton drill, chips, crackers, catfish, thousand stars and swallow) and node 3 (croton sheep and turtles) ) which is supported by a similarity index of 0.6 .

Keywords: Relationship; intraspecies; croton plant; Parigi Moutong; Phenetic

\section{PENDAHULUAN}

Tanaman hias kini menjadi komoditas tanaman hortikultura yang penting dikalangan masyarakat, terutama masyarakat perkotaan, karena bermanfaat untuk manambah kecantikan maupun keindahan (Handayati, 2013: 67-80). Salah satu tanaman hias yang sedang berkembang cukup baik dan banyak dicari oleh pecinta tanaman yaitu puring (Codiaeum variegatum). Puring memiliki nilai estetika dilihat dari ragam bentuk, corak dan warna daun yang begitu variatif sehingga dapat dijadikan sebagai penghias ruangan, tanaman landscape, ataupun tanaman penyerap polutan (Sulistiana, 2015: 3540; Trianto dan Marisa, 2020: 29-33).

Mollick et al. (2011: 71-79) melaporkan bahwa tanaman puring termasuk dalam famili Euphorbiaceae yang mempunyai jenis yang sangat banyak, dimana terdapat lebih dari sekitar 300 varietas puring yang ada di Dunia. Varietas puring yang banyak ditemui di Indonesia diantaranya yaitu puring jengkol, puring kura-kura, puring cobra, puring apel malang, puring bor merah, puring lele, puring jempol, dll (Gogahu et al., 2016: 76-80). Ragam varietas puring dapat dibedakan dari warna dan bentuk daun yang begitu variatif, warna daun terdiri dari warna hijau, merah, orange dan kuning dan variasi warnanya merupakan kombinasi dari warna dasar tersebut (Gogahu et al., 2016: 76-80). Bentuk daun yang dimiliki tanaman puring diantaranya yaitu lanset, lonjong, bulat telur, melengkung dan jorong (Muzayyinah, 2003: 43-46).

Keanekaragaman puring menjadikan tanaman ini menjadi salah satu tanaman dengan permintaan yang tinggi di pasaran, namun ketersediaanya belum dapat memenuhi kebutuhan pasar yang meningkat (Nasib et al., 2008: 99-104; Trianto et al., 2020: 154162). Beberapa penelitian sebelumnya telah dilakukan untuk kepentingan budidaya tanaman puring dari aspek molekuler (Deng et al., 2010: 868; Andreastuti, et al., 2015: 90-99; Trianto et al., 2020: 21-29). Oleh karena itu, upaya kajian tanaman puring perlu dilakukan untuk menunjang pembudidayaan tanaman tersebut.

Selain dari aspek molekuler kajian keanekaragaman puring dari aspek morfologi juga penting untuk dilakukan. Kajian morfologi sifatnya lebih mudah, cepat, sederhana dan relatif lebih murah. Karakter morfologi juga dapat digunakan untuk melihat kekerabatan antar kultivar yang diteliti (Widyaningsih, 2015: 68-71; Suprianto et al., 2020: 30-39; Trianto et al., 2020: 199-209; Trianto dan Purwanto, 2020: 186-193; Trianto dan Purwanto, 2020: 2619-2628), lebih lanjut melaporkan setiap tanaman memiliki deskripsi morfologi yang spesifik dan dapat digunakan sebagai penanda dari tanaman tersebut. Kajian morfologi dapat berperan dalam bidang pemuliaan tanaman yang diharapkan dapat dimanfaatkan dalam program pemuliaan untuk mendapatkan kultivarkultivar yang lebih variatif.

Salah satu kajian morfologi yang dapat dilakukan yaitu mempelajari hubungan kekerabatan intraspesies puring. Hubungan kekerabatan intraspesies puring dapat dilakukan dengan pengukuran kerakter morfometrik, meristik dan kualitatif. Hasil pengukuran morfologi selanjutnya diolah dalam software MVSP dengan menggunakan analisis klaster sehingga terbentuk dendogram yang menunjukkan hubungan kekerabatan pada sampel yang diteliti.

\section{METODE}

\section{Waktu dan Tempat Penelitian}


Penelitian ini dilaksanakan pada bulan Mei 2020 di Kecamatan Parigi Selatan. Jenis penelitian ini adalah penelitian deskriptif eksploratif, dilakukan di alam terbuka dengan tujuan untuk mengidentifikasi hubungan kekerabatan intraspesies tanaman puring.

\section{Alat dan Bahan}

Alat yang digunakan dalam penelitian ini berupa Mistar dan jangka sorong yang digunakan untuk mengukur morfologi tanaman puring. Termometer yang digunakan untuk mengukur suhu lingkungan area pembudidayaan, $\mathrm{pH}$ meter yang digunakan untuk mengukur $\mathrm{pH}$ tanah, hygrometer yang digunakan untuk mengukur kelembaban, kamera yang digunakan untuk mengambil Gambar karakter tanaman puring dan alat tulis menulis. Selanjutnya, mengukur kelembaban, kamera yang digunakan untuk mengambil Gambar karakter tanaman puring dan alat tulis menulis.

\section{Pelaksanaan Penelitian}

1) Melakukan observasi lapangan dengan pengamatan awal mengenai macam-macam puring yang dibudidayakan serta dikembangkan untuk keperluan tanaman hias.

2) Menyelesaikan administrasi penelitian.

3) Melakukan koordinasi pada pihak pengelolah budidaya tanaman hias yang akan dijadikan area pengamatan.

4) Menyiapkan alat dan bahan yang diperlukan saat proses penelitian dan pengukuran pada sampel.

5) Mengamati dan mengidentifikasi pertumbuhan tanaman puring untuk memperoleh kondisi kultifar tanaman yang homogen.

6) Melakukan pengukuran untuk setiap karakter dari sampel tanaman puring.

7) Melihat dan mengukur karakter morfometrik, meristik dan kualitatif setiap sampel tanaman puring.

8) Pengamatan dan pengkuran sampel dilakukan pada organ tanaman berupa, akar, batang dan daun. Setiap kultivar tanaman puring dilakukan pengukuran pada 5 individu tanaman yang tergolong satu kultivar dan setiap individu dilakukan pengukuran sebanyak 3 kali.

9) Melakukan wawancara pada pihak pengelolah tanaman hias untuk memperoleh informasi tambahan mengenai tanaman puring.

\section{Analisis Data}

Analisis data dilakukan dengan perhitungan nilai rata-rata, scoring dan penyusunan matriks $\mathrm{n} x \mathrm{t}$ menggunakan program Microsoft Exel.

a. Nilai Rata-Rata. Nilai rata-rata diperoleh setelah melakukan pengukuran terhadap karakter tanaman puring.

b. Scoring. Karakter- karakter yang diidentifikasi selanjutnya akan diberi nilai (skor) berdasarkan berbagai macam morfologi yang ada pada tanaman puring tersebut. Scoring merupakan penilaian berupa angka-angka yang berupa nilai kuantitatif dan kualitatif dari sifat maupun ciri morfologi yang telah terukur untuk menentukan Oprational Taxonomical Unit (OTU). Penilaian untuk mengukur karakter kualitatif skor yang diberikan yaitu 1 jika karakter kualitatif morfologinya terpenuhi dan 0 jika tak terpenuhi. 
c. Penyusunan Matriks $n \times t$. Matriks n $\mathrm{x} t$ ini sama dengan matriks nol - satu, dengan $\mathrm{n}$ adalah Oprational Taxonomical Unit (OTU) atau karakter tanaman puring dari masingmasing kultivar yang diteliti, sedangkan $t$ adalah unit karakter atau karakter yang dibandingkan pada tanaman puring.

d. Program File Editor (PFE). Setelah dilakukan penyusunan matriks $\mathrm{n} \times \mathrm{t}$, tabel yang tersusun tersebut kemudian dikopikan ke PFE dengan cara memblok matriks $\mathrm{n} \times \mathrm{t}$ dan klik copy kemudian klik paste pada program file editor.

e. Multivariat Statistical Package (MVS). Setelah data dianalisis dalam program PFE, selanjutnya data dimasukan kedalam program MVSP untuk dianalisis lebih lanjut. Metode yang digunakan dalam MVSP untuk melihat indeks similaritas adalah metode simple matcing coefisient dan penentuan hubungan kekerabatan menggunakan UPGMA algorithm. Berbagai tahapan analisis tersebut akan menampakan suatu dendogram yang menunjukan tingkat pengelompokan intraspesies puring yang diteliti dan indeks similaritas untuk melihat jauh dekatnya hubungan kekerabatan intraspesies puring.

\section{HASIL DAN PEMBAHASAN}

\section{Hasil}

Kultivar Tanaman Puring di Kecamatan Parigi Selatan untuk Pengukuran Variasi Karakter Morfometrik, Meristik dan Kualitatif

Morfometrik ialah ukuran yang bersifat kuantitatif yang diperoleh dari bagian tanaman puring. Pengukuran karakter tanaman puring meliputi tinggi tanaman, panjang tangkai daun, lebar helaian daun, lebar daun bagian ujung, lebar daun bagian pangkal, panjang batang dan diameter batang. Pengukuran meristik ialah sifat yang menunjukkan jumlah bagian-bagian yang ada pada organ tanaman. Karakter ini meliputi jumlah warna pada daun tanaman dan jumlah warna pada setiap helaian daun. Variasi karakter kualitatif meliputi warna, bentuk dan tekstur pada bagian-bagian organ tanaman yang dapat diamati secara langsung (Sulistiana, 2015: 1).

Berdasarkan hasil penelitian yang telah dilakukan di Kecamatan Parigi Selatan diperoleh 8 kultivar puring, diantaranya ialah puring bor/spiral, puring emping/dolar, puring kerupuk, puring tanduk, puring kura-kura, puring lele, puring walet, dan puring seribu bintang (Gambar 1).
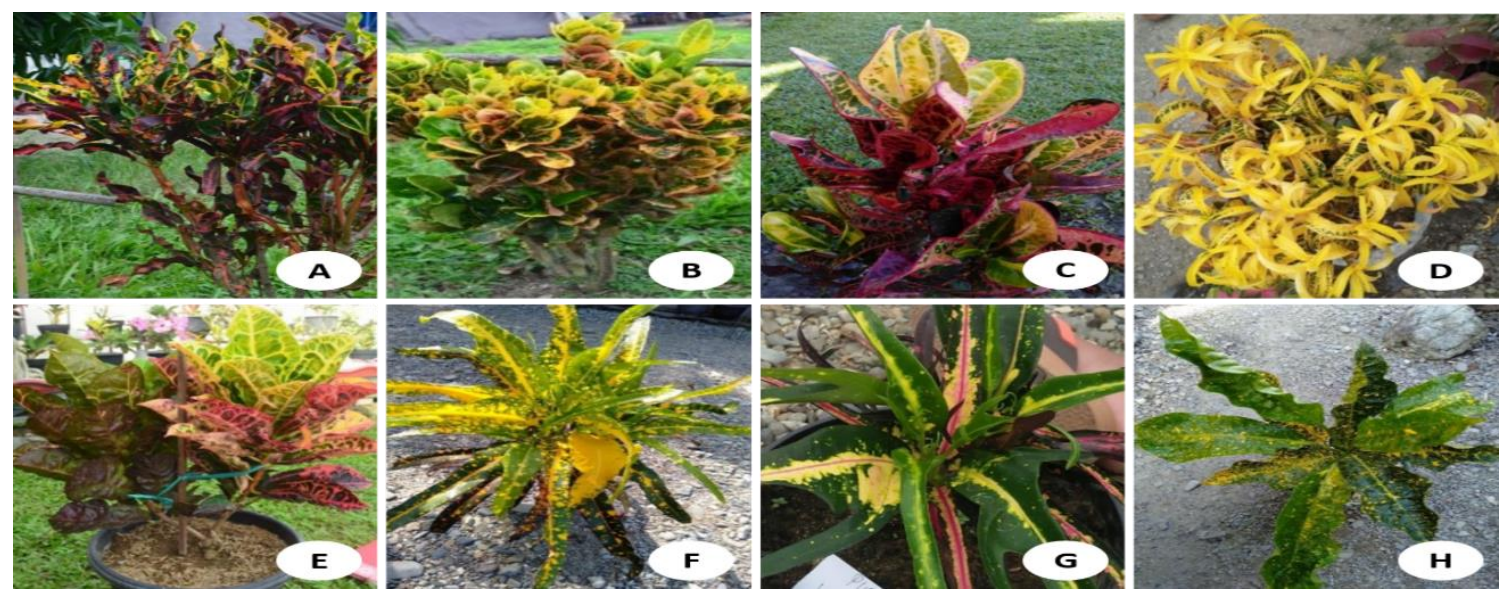

Gambar 1. Kultivar tanaman puring: A. Puring bor/spiral, B. Emping/dolar, C. Kerupuk, D. Tanduk domba, E. Kura-kura, F. Lele, G. Walet, dan H. Seribu bintang. 


\section{Pengujian Hubungan Kekerabatan Berdasarkan Kemiripan Karakter Diantara Kultivar Puring dengan Menggunakan Software Multivariat Statistical Package (MVSP)}

Berdasarkan hasil pengkuran karakter karakter morfometrik, meristik dan kualitatif yang telah dilakukan, nampak perbedaan dan variasi antar kultivar tanaman puring yang telah diteliti. Untuk mengetahui hubungan kekerabatan intraspesies tanaman puring dari data yang telah diperoleh, dilakukan pengujian menggunakan Software Multivariat Statistical Package (MVSP) yang merupakan perhitungan koefisien similarity dan analisis klasifikasi bertingkat sehingga diperoleh rekonstruksi dendogram yang dapat dilihat melalui Gambar 2.

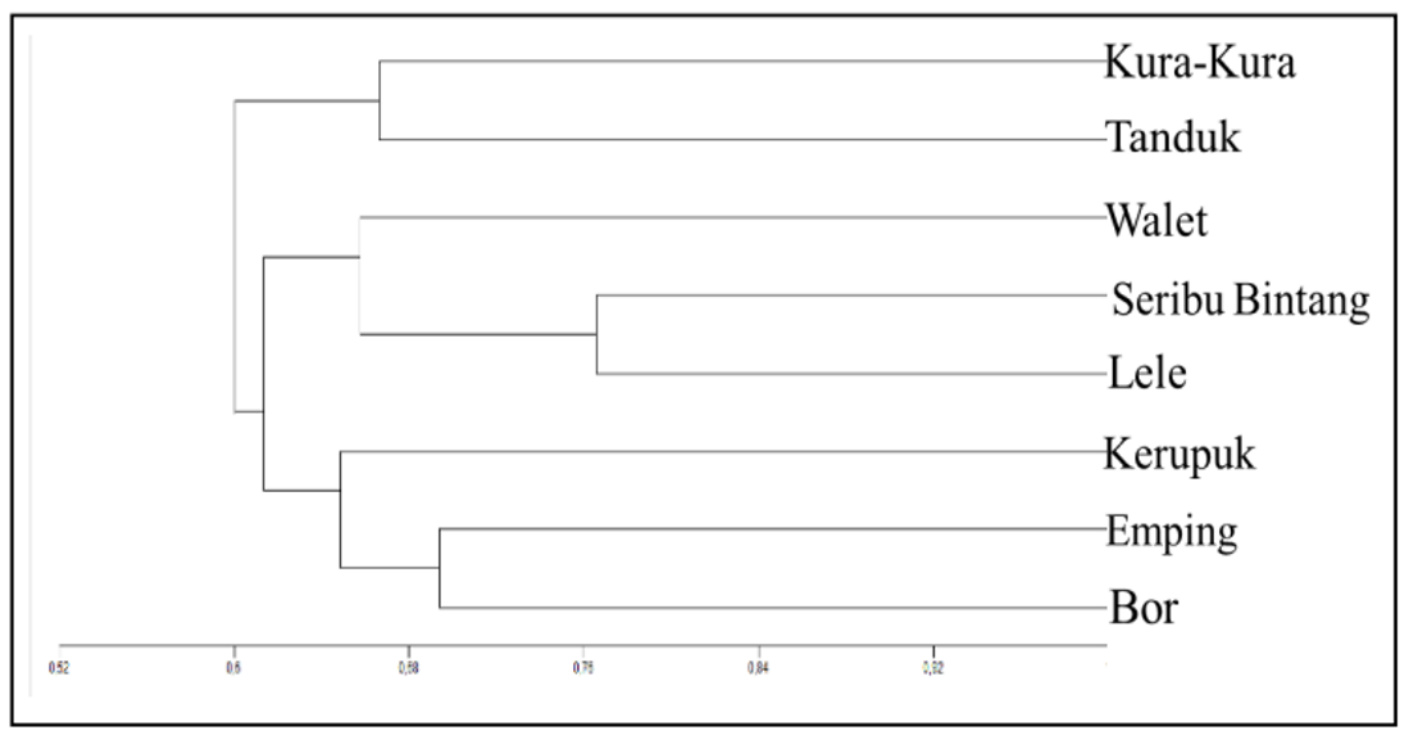

Gambar 2. Dendorgam intraspesies kultivar puring menggunakan software MVSP

Konstruksi dendogram pada Gambar 2 menunjukkan bahwa hubungan kekerabatan intraspesies tanaman puring masih berkerabat dekat. Kekerabatan terdekat terbentuk antara kultivar puring lele dan puring seribu bintang yang didukung dengan indeks similaritas 0,76 . Kekerabatan terjauh yaitu antar node 6 (puring bor, puring emping, puring kerupuk, puring lele, puring seribu bintang dan puring walet ) dan node 3 (puring Kura-kura dan puring domba) yang didukung dengan indeks similaritas 0,6. Dendogram pada Gambar 2 diperkuat melalui matriks koefisien gabungan yang menunjukkan indeks similaritas dari setiap klaster pada Tabel 1.

Tabel 1. Matriks koefisien gabungan 8 kultivar puring

\begin{tabular}{ccccc}
\hline Node & Group 1 & Group 2 & Simil. & Object in Grup \\
\hline 1 & Lele & Seribu bintang & 0,766 & 2 \\
2 & Bor & Emping & 0,694 & 2 \\
3 & Tanduk & Kura-kura & 0,667 & 2 \\
4 & Node 1 & Walet & 0,658 & 3 \\
5 & Node 2 & Kerupuk & 0,649 & 3 \\
6 & Node 5 & Node 4 & 0,614 & 6 \\
7 & Node 6 & Node 3 & 0,601 & 8 \\
\hline
\end{tabular}


Analisis klaster juga dilakukan pada seluruh individu tanaman yang telah diteliti yaitu masing masing 5 individu pada setiap kultivar menggunakan software Multivariat Statistical Package (MVSP) sehingga diperoleh rekonstruksi dendogram yang dapat dilihat pada Gambar 2.

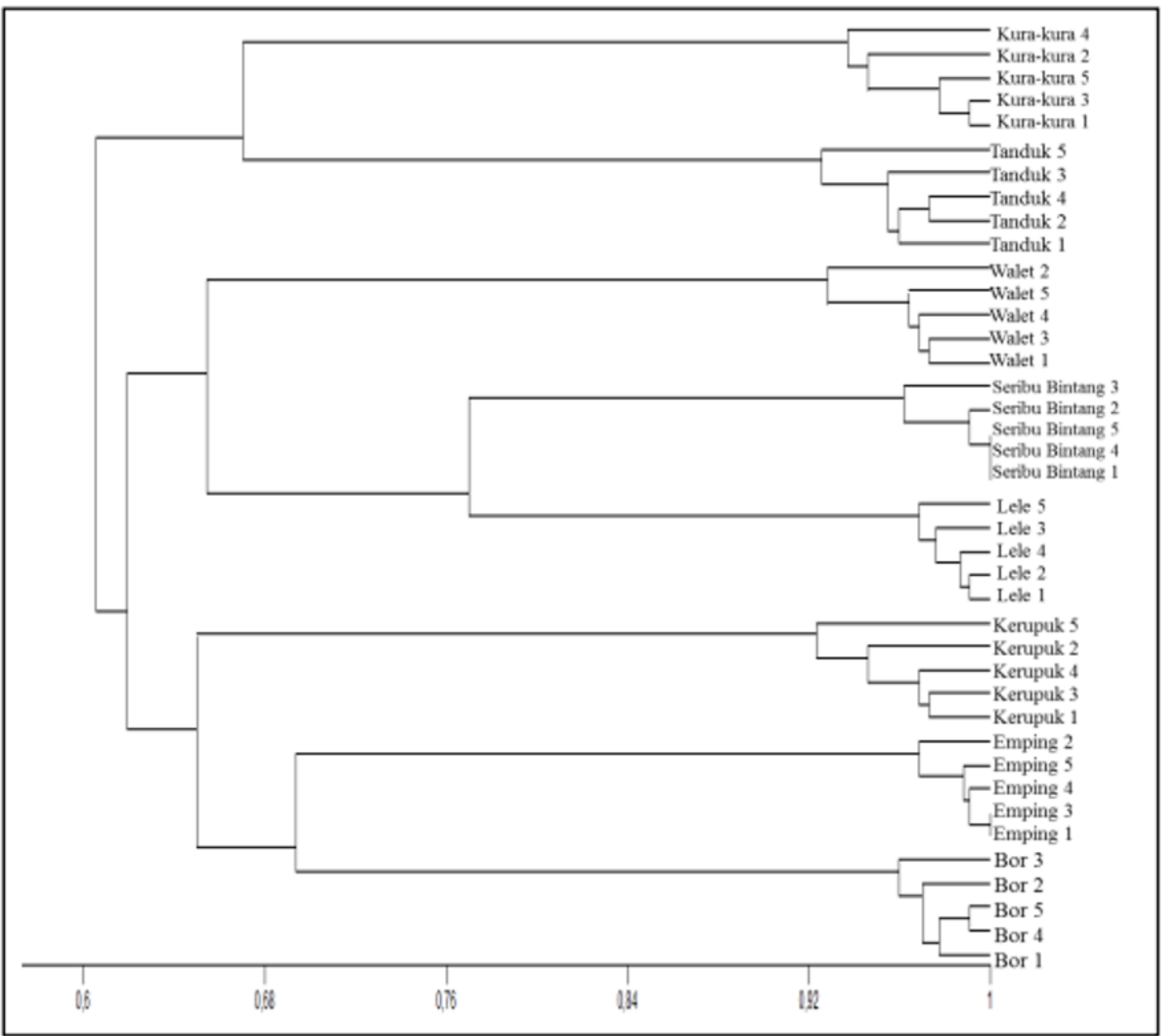

Gambar 3. Dendogram intraspesies puring dilihat dari seluruh individu yang diolah dalam analisis claster menggunakan software MVSP

Berdasarkan dendogram pada Gambar 3 data keseluruhan hasil seluruh pengukuran morfometrik, meristik dan kualitatif menunjukkan indeks kesamaan yang cukup stabil. Data masing-masing individu yang masih tergolong kultivar yang sama memiliki tingkat kesamaan yang cukup tinggi dan membentuk dendogram dengan node yang berdekatan. Individu yang berbeda kultivar memiliki indeks kesamaan yang rendah. Indeks similaritas dari seluruh individu pada semua kultivar dapat dilihat pada Tabel 2.

Tabel 2. Matriks koefisien gabungan seluruh individu dari 8 kultivar puring

\begin{tabular}{ccccc}
\hline Node & Group 1 & Group 2 & Simil. & Object in Grup \\
\hline 1 & Emping 1 & Emping 3 & 1 & 2 \\
2 & Seribu bintang 1 & Seribu bintang 4 & 1 & 2 \\
3 & Node 2 & Seribu bintang 5 & 1 & 3 \\
4 & Bor 4 & Bor 5 & 0,991 & 2
\end{tabular}




\begin{tabular}{|c|c|c|c|}
\hline Node 1 & Emping 4 & 0,991 & 3 \\
\hline Kura-kura 1 & Kra-kura 3 & 0,991 & 2 \\
\hline Lele 1 & Lele 2 & 0,991 & 2 \\
\hline Node 3 & Seribu bintang 2 & 0,991 & 4 \\
\hline Node 5 & Emping 5 & 0,988 & 4 \\
\hline Node 7 & Lele 4 & 0,986 & 3 \\
\hline Bor 1 & Node 4 & 0,977 & 3 \\
\hline Node 6 & Kura-kura 5 & 0,977 & 3 \\
\hline Node 10 & Lele 3 & 0,976 & 4 \\
\hline Kerupuk 1 & Kerupuk 3 & 0,973 & 2 \\
\hline Tanduk 2 & Tanduk 4 & 0,973 & 2 \\
\hline Walet 1 & Tanduk 4 & 0,973 & 2 \\
\hline Node 11 & Walet 3 & 0,970 & 4 \\
\hline Node 14 & Bor 2 & 0,968 & 3 \\
\hline Node 13 & Kerupuk 4 & 0,968 & 5 \\
\hline Node 16 & Lele 5 & 0,968 & 3 \\
\hline Node 9 & Emping 2 & 0,968 & 5 \\
\hline Node 20 & Walet 5 & 0,964 & 4 \\
\hline Node 8 & Seribu bintang 3 & 0,962 & 5 \\
\hline Node 17 & Bor 3 & 0,959 & 5 \\
\hline Tanduk 1 & Node 15 & 0,959 & 3 \\
\hline Node 25 & Tanduk 3 & 0,955 & 4 \\
\hline Node 12 & Kura-kura 2 & 0,946 & 4 \\
\hline Node 18 & Kerupuk 2 & 0,946 & 4 \\
\hline Node 27 & Kura-kura 4 & 0,937 & 5 \\
\hline Node 22 & Walet 2 & 0,928 & 5 \\
\hline Node 26 & Tanduk 5 & 0,926 & 5 \\
\hline Node 28 & Kerupuk 5 & 0,923 & 5 \\
\hline Node 19 & Node 23 & 0,770 & 10 \\
\hline Node 24 & Node 21 & 0,694 & 10 \\
\hline Node 31 & Node 29 & 0,670 & 10 \\
\hline Node 33 & Node 30 & 0,654 & 15 \\
\hline Node 34 & Node 32 & 0,650 & 15 \\
\hline Node 37 & Node 36 & 0,619 & 30 \\
\hline Node 38 & Node 35 & 0,605 & 40 \\
\hline
\end{tabular}

Tabel 2 menunjukkan indeks similaritas keseluruhan individu yang diteliti bahwa keragaman masing-masing individu yang masih tergolong dalam kultivar puring yang sama memiliki hubungan kekerabatan yang sangat dekat dengan kisaran indeks similaritas 0,92-1. Berbeda dengan hubungan kekerabatan intraspesies puring yang memiliki hubungan kekerabatan yang rendah dengan indeks similaritas $0,6-0,77$. Hal ini dipengaruhi oleh banyaknya variasi karakter yang diukur serentak pada semua jenis kultivar tanaman puring yang diperoleh.

\section{Pengukuran Kondisi Fisik dan Kimia Lingkungan}

Hasil pengukuran kondisi fisik kimia lingkungan yang diukur pada 3 tempat budidaya yang berbeda namun masih pada satu desa yang sama. Pengukuran kondisi fisik kimia lingkungan meliputi $\mathrm{pH}$, kelembaban dan suhu, diperoleh hasil sebagaimana yang terlihat pada Tabel 3. 
Tabel 3. Kondisi fisik kimia lingkungan

\begin{tabular}{cccccc}
\hline No & Parameter & \multicolumn{4}{c}{ Hasil Pengamatan } \\
\hline & & Lokasi 1 & Lokasi 2 & Lokasi 3 & Lokasi 4 \\
\hline 1 & pH tanah & 5,9 & 5,9 & 6,5 & 6,3 \\
2 & Kelembaban tanah & $80 \%$ & $70 \%$ & $80 \%$ & $55 \%$ \\
3 & Kelembaban udara & $71,5 \%$ & $71,5 \%$ & $70,4 \%$ & $74,6 \%$ \\
4 & Suhu & $30^{\circ} \mathrm{C}$ & $30^{\circ} \mathrm{C}$ & $30^{\circ} \mathrm{C}$ & $30^{\circ} \mathrm{C}$ \\
\hline
\end{tabular}

\section{Pembahasan}

Pengukuran karakter morfometrik, meristik dan kualitatif yang telah dilakukan menunjukkan adanya variasi ukuran, bentuk maupun warna yang ada pada setiap kultivar tanaman puring. Keragaman morfologi puring dikaji dari tingkat hubungan kekerabatanya menggunakan program Multivariat Statistical Package (MVSP) (Sulistiana, 2015: 1).

Hasil penelitian yang dikaji dari kultivar tanaman puring membentuk 3 klaster dan 2 subklaster. Dari ketiga klaster dapat diketahui bahwa kelompok puring lele dan seribu bintang memiliki kesamaan yang kuat dan sedikit sama dengan puring walet, dan sangat berbeda jauh dengan kultivar lain. Antara puring bor dan puring emping memiliki kesamaan yang erat, sedikit sama dengan puring kerupuk dan berbeda jauh dengan kultivar lain. Kelompok puring kura-kura memiliki kesamaan yang sangat erat dengan puring tanduk dan sangat berbeda jauh dengan kelompok puring lain. Adanya persamaan yang erat antar kelompok puring ini dikarenakan pada dasarnya puring tersebut masih dalam spesies yang sama dan merupakan tanaman yang dibudidayakan pada habitat yang cenderung sama. Adanya perbedaan yang menjadikan hubungan kekerabatan antar kultivar puring bervariasi dikarenakan adanya pengaruh gen yang menimbulkan variasi karakter morfologi yang berbeda-beda. Mollick (2011: 71-79) melaporkan bahwa genom tanaman puring memiliki Tyl-copia yang merupakan bagian DNA yang berperan dalam terjadinya mutasi sehingga menimbulkan keanekaragaman morfologi daun.

Klaster pertama ditempati oleh kelompok node 1 (puring seribu bintang dan puring lele) yang berkerabat dengan kelompok puring walet. Hal ini ditunjukkan oleh banyaknya persamaaan karakter yaitu 61 karakter yang sama. Karakter yang sama meliputi panjang helaian daun, diameter batang, memiliki dua warna pada setiap helaian daun, warna tangkai daun, warna ibu tulang daun, warna tepi daun, bentuk daun dewasa, warna daun dewasa dan pertulangan menyirip daun yang tidak terlihat jelas. Selain persamaan klaster ini memiliki sebanyak 50 karakter yang berbeda. Karakter yang berbeda meliputi panjang tangkai daun, lebar helaian daun, lebar daun bagian ujung, lebar pangkal daun, panjang batang, warna pangkal batang, warna helaian daun bagian bawah dan bentuk tepi helaian daun.

Klaster pertama membentuk subklaster yang terdiri dari kelompok puring seribu bintang dan puring lele. Subklaster ini mempunyai nilai indeks similaritas yang lebih tinggi karena memiliki lebih banyak karakter yang sama yaitu sebanyak 85 karakter. Persamaan karakter yang dimiliki meliputi panjang helaian daun, panjang tangkai daun, diameter batang, jumlah warna pada setiap helaian daun, warna dominan ujung batang, warna tangkai daun, warna tepi daun, warna helaian daun bagian bawah, bentuk daun muda, warna daun muda, bentuk ujung daun, bentuk tepi helaian daun, bentuk daun dewasa, warna daun dewasa, bentuk tepi helaian daun dan pertulangan menyirip daun yang tidak terlihat jelas. Secara umum persamaan morfologi yang dapat dilihat dari 
subklaster ini dapat dilihat dari ukuran panjang daun yang berukuran cukup panjang dengan kisaran panjang $>15 \mathrm{~cm}$ dan bentuk daun yang memiliki kemiripan. Deng et al. (2010:

mengelompokkan daun yang berukuran panjang yang dan besar kedalam kelompok yang sama.

Klaster kedua yaitu pada kelompok node 2 (puring bor dan emping) yang berkerabat dengan kelompok puring kerupuk. Hal ini ditunjukkan oleh banyaknya persamaaan karakter yaitu 55 karakter yang sama. Karakter yang sama meliputi panjang helaian daun, lebar helaian daun, jumlah warna pada setiap helaian daun,warna ibu tulang daun, warna tepi daun, warna daun bagian bawah, warna klaster ini memiliki sebanyak 56 karakter yang berbeda. Karakter yang berbeda meliputi panjang tangkai daun, lebar daun bagian ujung, warna dominan ujung batang, warna tangkai daun, bentuk pangkal helaian daun, bentuk daun muda dan dewasa, bentuk permukaan daun dan bentuk tepi helaian daun.

Polimorfisme genetik bisa menjadi faktor yang berkontribusi terhadap keragaman morfologi. Deng et al. (2010: 875) melaporkan hubungan genetik puring menggunakan penanda AFLP secara genetik sangat polimorfik, yang ditunjukkan dari hasil penelitian 44 kultivar puring memiliki jarak genetik 0,322 atau kurang, disisi lain 81\% dari 549 fragmen yang berisi informasi rata-rata 0,22 yang menunjukkan puring memiliki basis genetik sempit dan secara genetik sangat polimorfik. Ogunwenmo et al. (2007: 24012405) melaporkan variabilitas kromosom dapat menjelaskan berbegai variasi morfologi yang luas pada tanaman puring. Secara umum persamaan morfologi yang dapat dilihat langsung pada klaster ini yaitu memiliki ukuran panjang daun yang berkisar $<15 \mathrm{~cm}$ dengan lebar $<5 \mathrm{~cm}$. Widyaningsih, (2015: 80-83) yang menyatakan bahwa morfologi helaian daun yang memiliki ukuran panjang yang sama tergabung dalam kelompok yang berkerabat dekat. Selain itu klaster ini memiliki banyak kesamaan warna pada helaian daun.

Klaster kedua membentuk subklaster yang terdiri dari kelompok puring bor dan puring emping. Subklaster ini mempunyai nilai indeks similaritas yang lebih tinggi karena memiliki lebih banyak karakter yang sama yaitu sebanyak 77 karakter. Persamaan karakter yang dimiliki meliputi panjang helaian daun, lebar helaian daun, lebar daun bagian ujung, panjang batang, diameter batang, warna pangkal batang, warna ibu tulang daun, warna helaian daun bagian bawah, warna daun muda, bentuk ujung daun muda, warna daun dewasa dan pertulangan menyirip daun yang tidak terlihat jelas. Secara umum persamaan morfologi dari subklaster ini dapat dilihat dari panjang helaian dan lebar helaian daun serta dominan warna helaian daun yang berwarna hijau kemerahan dan hijau kekuningan.

Klaster ketiga ditempati oleh puring tanduk dan puring kura-kura hal ini ditunjukkan dengan persamaan karakter sebanyak 74 karakter. Karakter yang sama meliputi panjang helaian daun, panjang tangkai daun, panjang batang dan diameter batang, warna pangkal batang, warna tangkai daun, warna ibu tulang daun, warna tepi daun, bentuk pangkal helaian daun, warna daun muda, warna daun dewasa dan pertulangan menyirip daun yang terlihat jelas. Selain persamaan klaster ini memiliki sebanyak 37 karakter yang berbeda. Karakter yang berbeda meliputi lebar helaian daun, lebar daun bagian ujung, lebar daun bagian pangkal, warna dominan ujung batang, warna helaian daun bagian bawah, bentuk daun muda, bentuk ujung helaian daun, bentuk tepi helaian daun, bentuk daun dewasa dan bentuk permukaan helaian daun. Secara umum persamaan morfologi dari klaster ini dapat dilihat dari ukuran panjang daun yang berkisar 
$<15 \mathrm{~cm}$, warna tangkai daun yang berwarna hijau kekuningan, dan warna daun dewasa yang didominasi oleh warna hijau kekuningan.

Variasi warna juga nampak pada masing-masing individu yang tergolong pada jenis yang sama. Keindahan pada warna daun puring telah diwujudkan kedalam 13 kombinasi warna yang berbeda yang ditampilkan pada 10-26 daun, sehingga tidak ada dua daun yang memiliki pola yang identik (Ogunwenmo et al., 2007: 2402). Variasi warna yang dinampakkan pada daun puring dipengaruhi oleh keragaman genetik pada kultivar tanaman puring. Andreastuti (2015: 93-95) mengemukakan bahwa sampel daun puring dengan kelompok warna hijau-kuning dan hijau merah (bicolor) memiliki jumlah alel yang paling banyak dibandingkan dengan kelompok puring dengan warna hijau (monocolor) sehingga menunjukkan bahwa kelompok puring bicolor memiliki tingkat keragaman genetik paling tinggi ‘diantara kelompok warna lain.

Karakter kualitatif yang paling menonjol yang membedakan antara kultivar satu dengan yang lain yaitu pada bentuk, warna dan corak pada daun puring. Secara umum, karakeristik morfologi daun dapat bervariasi antar spesies yang berbeda, individu yang berbeda dari spesies yang sama atau dalam individu pada tahap perkembangan yang berbeda (Dickinson et al., 1987: 15-20).

Variasi karakter morfometrik pada kultivar yang diteliti dapat dipengaruhi oleh faktor lingkungan, ketersediaan unsur hara dan kondisi lingkungan yang baik dapat mengoptimalkan ukuran helaian pada daun puring. Didukung oleh penelitian Widyaningsih (2015: 65-69) yang mengatakan bahwa karakter kuantitatif morfologi daun seperti panjang helaian daun, lebar helaian daun, dan panjang tangkai daun merupakan karakter kuantitatif yang dapat dipengaruhi oleh lingkungan. Selain itu, lokasi tempat tanaman diletakkan juga dapat berpengaruh umumnya tanaman puring yang di tempatkan di halaman dengan paparan sinar matahari yang panjang mempunyai corak dan warna daun yang lebih variatif dibandingkan dengan tanaman puring yang di letakkan pada tempat teduh. Kadir (2008: 42-51) menyatakan cahaya yang cukup membuat warna daun dapat berkembang secara optimal, sebaliknya kekurangan cahaya dapat membuat warna tertentu tidak atau kurang muncul. Hal tersebut juga didukung oleh hasil penelitian yang telah dilakukan Sophonputtanaphoca et al. (2000: 257-259) tentang adaptasi puring dengan tingkat intensitas cahaya berbeda.

Variasi morfologi yang nampak pada intraspesies puring menunjukkan indeks similaritas yang berbeda-beda dengan tingkat hubungan kekerabatan yang semakin jauh tergantung dari banyaknya perbedaan dan variasi yang terbentuk pada masing-masing kultivar (Rideng, 1986: 88). Hasil analisis hubungan kekerabatan yang ditunjukkan oleh Gambar 4.12 memperlihatkan dendogram intraspesies puring yang memiliki banyak kesamaan karakter morfologi, kelompok yang tergolong berkerabat sangat dekat dilihat pada subklaster pertama yaitu kelompok puring lele dan puring seribu bintang yang didukung dengan indeks similaritas 0,76. Kelompok puring yang memiliki hubungan kekerabatan terjauh dilihat pada node 6 (puring bor, emping, kerupuk, lele, seribu bintang, dan walet) dengan node 3 (puring tanduk dan kura-kura) didukung dengan indeks similaritas 0,6 hal ini deisebabkan adanya perbedaan dan variasi karakter morfologi. Menurut

Fitriana (2014: 187-250) menggolongkan tingkat hubungan kekerabatan yaitu indeks similaritas $\geq 0,75$ (sangat dekat), 0,51-0,74 (dekat), 0,26-0,50 (tidak dekat), $\leq 0,25$ (sangat tidak dekat). 


\section{KESIMPULAN DAN SARAN \\ Kesimpulan}

Hubungan kekerabatan yang diperoleh dari 8 kultivar puring membentuk 3 klaster dan dua subklaster yang menunjukan hubungan kekerabatan yang dekat. Hubungan kekerabatan paling dekat yaitu pada kultivar puring lele dan kultivar puring seribu bintang didukung dengan indeks similaritas yaitu 0,76 Hubungan kekerabatan terjauh yaitu antara node 6 (puring bor, emping, kerupuk, lele, seribu bintang, dan walet) dengan node 3 (puring tanduk dan kura-kura) didukung dengan indeks similaritas 0,6.

\section{Saran}

Perlu dilakukan studi lebih lanjut mengenai kultivar tanaman puring yang belum diteliti mengingat banyaknya kultivar tanaman puring yang mengalami perkembangan cukup pesat sehingga kajian mengenai tanaman puring dapat di perluas tidak hanya dari aspek morfologi namun juga dari aspek lain.

\section{DAFTAR RUJUKAN}

Andreastuti, M., Purwantoro, A., \& Murti, R.H. (2015). Keragaman molekuler puring (Codiaeum variegatum (L.) Rumph. ex A. Juss) dengan penanda RAPD. Vegetalika, 4(2), 90-99.

Deng, M., Chen, J., Henny, R.J., \& Li, Q. (2010). Genetic relationships of Codiaeum variegatum cultivars analyzed by amplified fragment length polymorphism markers. Hortiscience, 45(6), 868-874.

Dickinson, T.A., Parker, W.H., \& Strauss, R.E. (1987). Another approach to leaf shape comparisons. Taxon, 36(3), 1-20.

Fitriana \& Hasanuddin. (2014). Hubungan kekerabatan fenetik 12 spesies anggota familia Asteraceae. Jurnal EduBio Tropika, 2(2), 187-250.

Gogahu, Y., Ai, N.S., \& Siahaan, P. (2016). Konsentrasi klorofil pada beberapa varietas tanaman puring (Codiaeum varigatum L.). Jurnal MIPA UNSRAT, 5(2), 76-80.

Handayati, W. (2013). Perkembangan pemuliaan mutasi tanaman hias di Indonesia. Jurnal Ilmiah Aplikasi Isotop dan Radiasi, 9(1), 67-80.

Kadir, A. (2008). Puring. Yogyakarta: Andi Offset.

Mollick, A.S., Shimoji, H., Denda, T., Yokota, M., \& Yamasaki, H. (2011). Croton Codiaeum variegatum (L.) Blume cultivars characterized by leaf phenotypic parameters. Hort Science, 132(2), 71-79.

Muzayyinah. (2003). Keragaman puring (Codiaeum variegatum (Linn.) Blume) di Daerah Istlmewa Yogyakarta. Biodiversitas Journal of Biological Diversity, 4(1), 4346.

Nasib, A., Ali, K., \& Khan, S. (2008). In vitro propagation of Croton (Codiaeum variegatum). Pak. J. Bot, 40(1), 99-104.

Ogunwenmo, K.O., Indowu, O.A., Innocent, C., Esan, E.B., \& Oyelana, O.A. (2007). Cultivars of Codiaeum variegatum (L.) Blume (Euphorbiaceae) show variability in phytochemical and cytological characteristics. African Journal of Biotechnology, 6(20), 2401-2405.

Rideng, M.I. (1986). Taksonomi Tumbuhan Biji. Jakarta: Depdikbud Dirjen Dikti Pengembangan Lembaga Pendidikan Tenaga Kependidikan.

Sophonputtanaphoca, S., Chadchawan, S., \& Boon, L.P. (2000). Adaptation of croton Baisom (Codiaeum variegatum (L.) B1. 'Baisom) leaves to different light intensities. J Scie Res Chula Univ, 25(2), 257-269. 
Sulistiana, S. (2015). Kemampuan penyerapan timbal (pb) pada beberapa kultivar tanaman puring (Codiaeum variegatum). Jurnal Matematika Sains dan Teknologi, 16(1), 35-40.

Suprianto, Trianto, M., Alam, N., \& Kirana, N.G.A.G.C. (2020). Karakter morfologi dan analisis daerah conserved gen elongation factor 1a (EF1a) pada Lepidotrigona terminata. Jurnal Metamorfosa, 7(2), 30-39.

Trianto, M., \& Marisa, F. (2020). Diversity of bees and wasp (Hymenoptera) in cowpea (Vigna sinensis L.) in agricultural area at Martapura District, Banjar Regency, South Kalimantan. Journal of Science and Technology, 9(2), 29-33.

Trianto, M., \& Purwanto, H. (2020). Molecular phylogeny of stingless bees in the Special Region of Yogyakarta revealed using partial 16S rRNA mitochondrial gene. Buletin Peternakan, 44(4), 186-193.

Trianto, M., \& Purwanto, H. (2020). Morphological characteristics and morphometrics of Stingless Bees (Hymenoptera: Meliponini) in Yogyakarta, Indonesia. Biodiversitas, 21(6), 2619-2628.

Trianto, M., Kaini, Saliyem, Warsih, E., \& Winarsih. (2020). Keanekaragaman serangga polinator pada tanaman nanas (Ananas comosus (L.) Merr.) di Desa Bincau. Jurnal Penelitian Science dan Pendidikan, 9(2), 154-162.

Trianto, M., Marisa, F., \& Siswandari, N.P. (2020). Kelimpahan nisbi, frekuensi, dan dominansi jenis lalat di beberapa Pasar Tradisional di Kecamatan Martapura. Jurnal Metamorfosa, 7(2), 21-29.

Trianto, M., Marisa, F., \& Sukmawati. (2020). Keanekaragaman jenis rayap pada perkebunan kelapa sawit dan perkebunan karet di Kabupaten Banjar, Kalimantan Selatan. Jurnal Biologi Makassar, 5(2), 199-209.

Widyaningsih, R. (2015). Keanekaragaman Morfologi Puring (Codiaeum variegatum(L.) Blume) Di Kampus Institut Pertanian Bogor. [Skripsi]. Bogor: Institut Pertanian Bogor. 